\title{
Troponine I versus Creatinine Kinase-MB as Predictor Markers of the Severity and Outcomes in Acute Theophylline Toxicity
}

\author{
Aliaa A. Hodeib ${ }^{1}$; Mona M. Ghonem ${ }^{1}$
}

\begin{tabular}{ll}
\hline & ABSTRACT \\
\cline { 2 - 3 } $\begin{array}{l}\text { KEYWORDS } \\
\text { Theophylline; }\end{array}$ & $\begin{array}{l}\text { Theophylline is a bronchodilator drug that is used in the treatment of asthma } \\
\text { chronic obstructive pulmonary diseases. Cardiovascular complications } \\
\text { Acute poisoning; } \\
\text { Troponin I; } \\
\text { Creatine kinase-MB; } \\
\text { Cardiac damage. }\end{array} \quad \begin{array}{l}\text { intoxicate to morbidity and mortality that associate acute theophylline } \\
\text { kinase-MB as predictors of the severity and outcomes in cases of acute theophylline } \\
\text { intoxication. This prospective cohort study included thirty one patients with acute } \\
\text { theophylline toxicity admitted to Tanta Poison Control Center during the period } \\
\text { from the first of March } 2018 \text { to the end of February 2019. Patients were subjected } \\
\text { to personal and toxicological history taking, vital signs collection, grading of acute } \\
\text { theophylline toxicity and measurement of serum theophylline level. Both troponin I } \\
\text { and creatine kinase-MB were measured at admission and 12 hours post admission. } \\
\text { Results revealed that, troponin I at time of admission and 12 hours post admission } \\
\text { in addition to creatine kinase-MB } 12 \text { hours post admission were significantly } \\
\text { higher in cases with severe acute theophylline intoxication and patients who } \\
\text { required intensive care unit admission. It was concluded that, troponin I could } \\
\text { predict the severity and the requirement of intensive care unit admission in acute } \\
\text { theophylline toxicity either with early or delayed presentation. On the other hand, } \\
\text { creatine kinase-MB could be considered for patients with delayed presentation. }\end{array}$ \\
\hline
\end{tabular}

Introduction

Theophylline is a xanthine derivative that acts primarily through stimulation of endogenous catecholamines release. Catecholamines stimulate beta-2 adrenoceptors causing pulmonary bronchodilation, so theophylline has been effectively used in the treatment of asthma and chronic obstructive pulmonary disease (Fisher and Graudins, 2015).

\footnotetext{
${ }^{\text {(1) Forensic Medicine and Clinical Toxicology }}$

Department, Faculty of Medicine, Tanta University.

*aliaa.hodeib@gmail.com,mona.ghonaim@med.tanta.edu.eg 01006000839,01064257070
}

Despite the effective bronchodilator effects of theophylline, its use is extremely lowered in developed countries because of its narrow therapeutic index and relatively high frequency of side effects along with production of safer and more effective bronchodilator drugs. Nevertheless, it is still widely used and considered a preferred drug in the majority of the developing countries due to its low cost (Navid et al., 2016).

Theophylline at both therapeutic and toxic doses blocks adenosine receptors. Moreover, theophylline at toxic doses inhibits phosphodiesterase causing increased cyclic adenosine monophosphate with subsequent 
increase of adrenergic activation and catecholamine release (Wilson, 2008).

Acute theophylline intoxication may occur following single ingestion of a toxic dose that is estimated by more than $10 \mathrm{mg} / \mathrm{kg}$ in adults (Henry and Minton, 2011). Chronic intoxication occurs as a result of repeated ingestion of excessive theophylline doses over 72 hours (Shannon and Perry, 2005).

Clinical manifestations of acute theophylline toxicity include nausea and vomiting as well as sinus, supraventricular and ventricular tachycardia. Neurological effects include anxiety, agitation, tremors and seizures (Hocaoğlu et al., 2014; Fisher and Graudins, 2015). The most common metabolic disturbances reported in acute theophylline toxicity are hypokalaemia, hyperglycaemia, lactic acidosis, hypomagnesaemia and hypophosphataemia (Altaie et al., 2011).

Diagnosis of acute theophylline toxicity is based mainly on history and clinical manifestations. For screening and quantitative determination of serum levels of theophylline, liquid chromatography/electrospray mass spectrometry (LC/MS) can be used (Hori et al., 2006).

Treatment of acute theophylline toxicity is based mainly on general supportive measures that include care of the airway and control of hypotension, dysrhythmias, vomiting and seizures (Nasir et al., 2009; Murray, 2015). Gastric lavage followed by activated charcoal is effective even with delayed presentation because of sustainedrelease preparations. As theophylline undergoes enterohepatic circulation, multiple dose activated charcoal is useful in enhancement of its elimination (Al Qadheeb, 2012).

Cardiovascular complications represent a major contribution for morbidity and mortality in cases with acute theophylline intoxication.
The exact mechanism of cardiac toxicity is still not well defined. However, increased circulating catecholamines and antagonism of cardiac adenosine receptors are thought to be the predisposing factors (Shannon, 2007; Paul et al., 2010).

There were reports of cardiac muscle affection in theophylline intoxication (Starakis et al., 2003; Shamsuzzaman et al., 2016). However, cardiac enzymes are not widely investigated in acute theophylline toxicity. Thereafter, the current study was designed to investigate troponin I and creatine kinase-MB (CK-MB) as predictors of the severity and outcomes in cases of acute theophylline toxicity.

\section{Patients and Methods:}

\section{Study design and population:}

This prospective cohort study was conducted on patients with acute theophylline toxicity admitted to Tanta Poison Control Center during the period from the first of March 2018 to the end of February 2019.

Diagnosis of acute theophylline toxicity based on:

1- History of theophylline ingestion.

2-Manifestations of acute theophylline toxicity.

3-Determination of serum theophylline level.

\section{Inclusion criteria:}

Patients aged 18 years or more with acute suicidal or accidental theophylline intoxication were included in the study.

\section{Exclusion criteria:}

Patients with mixed intoxication, patients with pre-existing diseases (cardiac 
diseases, hypertension, diabetes mellitus and both hepatic \& renal diseases) and those with associated trauma were excluded. Patients who received any medications before hospital admission were also excluded.

\section{Ethical consideration:}

The study was carried out after approval of the Research Ethical Committee Faculty of Medicine - Tanta University (Approval code: 31935/11/17). All participants received full information about the scope of the study. A written informed consent was obtained from each participant or from his/her guardian. Confidentiality and privacy were maintained.

\section{Methods:}

All patients were subjected to the following:

\section{1- History taking:}

Detailed history; personal, toxicological and medical history of involved patients was obtained. Personal data included name, age, sex, occupation, education, residence and marital state of the patients. Toxicological history including type and amount of theophylline ingested, manner of poisoning and pre-hospitalization period was obtained.

\section{2- Clinical examination:}

Vital signs (blood pressure, pulse rate, respiratory rate and temperature) were recorded. According to Flomenbaum et al. (2006) and Middleton (2008), normal ranges of vital signs in adults are 90-130/60-90 $\mathrm{mmHg}$ for blood pressure, $60-100$ beats/minute for pulse rate, 16-24 cycles/minute for respiratory rate and 36.5$37.5^{\circ} \mathrm{C}$ for temperature.
According to Lim et al. (2005), symptoms and signs of acute theophylline intoxication were graded into mild (anorexia, nausea, vomiting, palpitations, nervousness, insomnia and tachycardia), moderate (symptoms of mild poisoning plus wide pulse pressure, initial hypertension then hypotension, tremors, agitation and hyperthermia) and severe (symptoms of moderate poisoning plus seizures, ventricular arrhythmias, extreme hyperthermia with dehydration, severe hypotension and coma).

\section{3- Laboratory investigations:}

Blood samples were collected under complete aseptic conditions. Immediately after admission and before administration of any medications, an arterial and venous blood samples were obtained. The arterial blood sample $(2 \mathrm{ml})$ was used for measurement of arterial blood gases using an ion selective electrode (Rapid lab 855, Bayer Company, USA) according to Kokholm (1990) and serum electrolytes using an ion selective electrode according to Woo (1999). The venous sample (3 ml) was used for measurement random blood glucose, troponin I, CK-MB and serum theophylline levels. Random blood sugar was measured according to Trinder (1969) using kits obtained from BioSystem S.A. Costa Brava, 30. 08030 Bracelona (Spain). Serum theophylline level was measured according to Sheehan and Haythorn (1976).

Measurement of Troponine I was done based on sandwich immune detection method using kits obtained from Guangzhou Wondfo Biotech Co.,Ltd (normal troponin I level is less than $0.3 \mathrm{ng} / \mathrm{ml}$ ). Creatine kinase-MB was measured based on kinetic colorimetric method using kits obtained from Egyptian company for biotechnology (normal CK-MB level is less than $25 \mathrm{U} / \mathrm{L}$ ). 
Both troponin I and CK-MB were measured twice. The first measurement was at admission; troponin I (1) and CK-MB (1). The second measurement was 12 hours post admission; Troponin I (2) and CK-MB (2).

\section{Outcome measures:}

The primary outcome measure was mortality. Secondary outcome measures were the need for intensive care unit (ICU) admission, need for hemodialysis and duration of hospital stay.

\section{Statistical analysis:}

Data was analyzed using SPSS software for windows, version 22. For quantitative data, the Shapiro-Wilk test for normality was performed. For normally distributed data, values were expressed as mean \pm standard deviation (SD). For data that was not normally distributed median and interquartile range (IQR, expressed as $25^{\text {th }}-75^{\text {th }}$ percentiles) were calculated. Mann-Whitney and Kruskal-Wallis tests were used for comparison between two and three groups respectively. Wilcoxon signed ranks test was used to compare between paired samples. As regards qualitative data, they were represented as frequency (number and percentage). Receiver operation characteristics (ROC) curve analysis was carried out to test the discrimination power of the studied parameters to predict the outcome. Areas under ROC curve (AUC), sensitivity and specificity were calculated. Pairwise comparisons were conducted to assess differences between AUCs of the studied parameters. Significance was adopted at $p<$ 0.05 for interpretation of results of tests.

\section{Results}

The current study was conducted on 31 patients presented by acute theophylline poisoning who have fulfilled the eligibility criteria during the study duration. Sociodemographic data and toxicological characteristics are demonstrated in table (1). The age of the participants ranged from 18 to 38 years and females represented $74.2 \%$ of the participants. The majority of cases were moderately educated $(87.1 \%)$ and from urban areas $(80.6 \%)$. Students represented $61.3 \%$ of all subjects. Most cases were single (67.7\%) and non-smokers (77.4\%). Regarding toxicological characteristics, the majority of cases $(87.1 \%)$ alleged suicidal ingestion. Sustained-release preparations were registered for $83.9 \%$ of cases. The alleged ingested theophylline dose ranged from 1000 to 6000 $\mathrm{mg}$ and the pre-hospitalization period ranged from 0.5 to 13 hours. 
Table (1): Socio-demographic data and toxicological characteristics of the studied patients with acute theophylline toxicity $(\mathrm{n}=31)$.

\begin{tabular}{|c|c|c|}
\hline \multicolumn{2}{|c|}{ Characteristic variables } & n $(\%)$ \\
\hline \multirow{2}{*}{ Age (years) } & Range & $18.0-38.0$ \\
\hline & Mean \pm SD & $22.9 \pm 5.9$ \\
\hline \multirow{2}{*}{ Sex } & Female & $23(74.2 \%)$ \\
\hline & Male & $8(25.8 \%)$ \\
\hline \multirow{2}{*}{ Education } & Moderate & $27(87.1 \%)$ \\
\hline & High & $4(12.9 \%)$ \\
\hline \multirow{2}{*}{ Residence } & Rural & $6(19.4 \%)$ \\
\hline & Urban & $25(80.6 \%)$ \\
\hline \multirow{3}{*}{ Occupation } & Housewife & $9(29.0 \%)$ \\
\hline & Student & $19(61.3 \%)$ \\
\hline & Worker & $3(9.7 \%)$ \\
\hline \multirow{2}{*}{ Marital state } & Married & $10(12.3 \%)$ \\
\hline & Single & $21(67.7 \%)$ \\
\hline \multirow{2}{*}{ Special habits } & Non-smoker & $24(77.4 \%)$ \\
\hline & Smoker & $7(22.6 \%)$ \\
\hline \multirow{2}{*}{ Mode of poisoning } & Alleged suicidal & $27(87.1 \%)$ \\
\hline & Alleged accidental & $4(12.9 \%)$ \\
\hline \multirow{2}{*}{ Type of preparation } & Conventional & $5(16.1 \%)$ \\
\hline & Sustained-release & $26(83.9 \%)$ \\
\hline \multirow{2}{*}{$\begin{array}{l}\text { Alleged ingested theophylline dose } \\
\text { (mg) }\end{array}$} & Range & $1000-6000$ \\
\hline & Median (IQR) & $2000(2000-2500)$ \\
\hline \multirow{2}{*}{ Delay time (hours) } & Range & $0.5-13$ \\
\hline & Median (IQR) & $5.0(4.0-12.0)$ \\
\hline
\end{tabular}

n: number; SD: standard deviation; IQR: interquartile range; mg: milligram.

Clinical manifestations and initial laboratory findings are summarized in table (2). For vital signs, hypotension, tachycardia, hyperthermia and tachypnea were represented in $77.4 \%, 93.5 \%, 71 \%$ and $71 \%$ of the studied patients respectively. Nausea was observed in all patients whereas, vomiting and abdominal colic were registered for $96.8 \%$ and $61.3 \%$ respectively. Tremors, agitation and disturbed level of consciousness were observed in
$41.9 \%, 38.7 \%$ and $6.5 \%$ of the patients respectively. Regarding blood glucose level, $32.3 \%$ of the patients were hyperglycemic. Acidosis was observed in $22.6 \%$ of the cases. The majority of cases $(64.5 \%)$ were presented with mild intoxication, while $12.9 \%$ and $22.6 \%$ were presented with moderate and severe intoxication respectively. For theophylline level, it ranged from 20 to 100 mg/L (median: $34 \mathrm{mg} / \mathrm{L}$ ) 
Table (2): Clinical manifestations, initial laboratory findings, grading of poisoning severity and serum theophylline level of the studied patients with acute theophylline toxicity $(n=31)$.

\begin{tabular}{|c|c|c|}
\hline Variables & $\mathbf{n}$ & $\%$ \\
\hline \multicolumn{3}{|l|}{ Blood pressure } \\
\hline Normal & 7 & 22.6 \\
\hline Hypotension & 24 & 77.4 \\
\hline \multicolumn{3}{|l|}{ Pulse } \\
\hline Normal & 2 & 6.5 \\
\hline Tachycardia & 29 & 93.5 \\
\hline \multicolumn{3}{|l|}{ Temperature } \\
\hline Normal & 22 & 71.0 \\
\hline Hyperthermia & 9 & 29.0 \\
\hline \multicolumn{3}{|l|}{ Respiratory rate } \\
\hline Normal & 9 & 29.0 \\
\hline Tachypnea & 22 & 71.0 \\
\hline \multicolumn{3}{|l|}{ Gastrointestinal manifestations } \\
\hline Nausea & 31 & 100.0 \\
\hline Vomiting & 30 & 96.8 \\
\hline Abdominal colic & 19 & 61.3 \\
\hline \multicolumn{3}{|l|}{ Neurological manifestations } \\
\hline Tremors & 13 & 41.9 \\
\hline Agitation & 12 & 38.7 \\
\hline Disturbed consciousness & 2 & 6.5 \\
\hline \multicolumn{3}{|l|}{ Glycemic state } \\
\hline Normal & 21 & 67.7 \\
\hline Hyperglycemia & 10 & 32.3 \\
\hline \multicolumn{3}{|l|}{ Potassium level } \\
\hline Normal & 7 & 22.6 \\
\hline Hypokalemia & 24 & 77.4 \\
\hline \multicolumn{3}{|l|}{ pH } \\
\hline Normal & 24 & 77.4 \\
\hline Acidosis & 7 & 22.6 \\
\hline \multicolumn{3}{|l|}{ Acute theophylline toxicity grading } \\
\hline Mild & 20 & 64.5 \\
\hline Moderate & 4 & 12.9 \\
\hline Severe & 7 & 22.6 \\
\hline \multirow{2}{*}{ Serum theophylline level $(\mathrm{mg} / \mathrm{L})$} & Range & $20-100$ \\
\hline & Median (IQR) & $34.0(33.0-70.0)$ \\
\hline
\end{tabular}

n: number; mg: milligram; L: liter; IQR: interquartile range.

As illustrated in table (3), the median values of troponin I and CK-MB at time of admission were $0.08 \mathrm{ng} / \mathrm{ml}$ and $24 \mathrm{U} / \mathrm{L}$ respectively. While, their median values 12 hours post admission were $0.01 \mathrm{ng} / \mathrm{ml}$ and 17 $\mathrm{U} / \mathrm{L}$ for troponin I and CK-MB respectively. 
Table (3): Level of troponin I and creatine kinase-MB at time of admission and 12 hours post admission in the studied patients with acute theophylline toxicity $(n=31)$

\begin{tabular}{|l|c|c|}
\hline \multicolumn{1}{|c|}{ Variables } & Range (ng/ml) & Median (IQR) (ng/ml) \\
\hline Troponin I (1) & $0.04-1.40$ & $0.08(0.08-0.10)$ \\
\hline Troponin I (2) & $0.01-3.00$ & $0.01(0.01-0.11)$ \\
\hline & Range (U/L) & Median (IQR) (U/L) \\
\hline CK-MB (1) & $10.0-28.0$ & $24.0(22.0-25.0)$ \\
\hline CK-MB (2) & $12.0-77.0$ & $17.0(13.0-60.0)$ \\
\hline
\end{tabular}

Troponin I (1): troponin at time of admission; Troponin I (2): troponin 12 hours post admission; CK-MB (1): creatine kinase-MB at admission; CK-MB (2): creatine kinase-MB 12 hours post admission; ng: nanogram; ml: milliliter; U: unit; L: liter; IQR: interquartile range.

Data obtained from the current study revealed that, all cases survived. Only one case underwent hemodialysis while, three cases
$(9.7 \%)$ required ICU admission. The duration of hospital stay ranged from 24 to 96 hours with mean value 45.8 hours (Table 4 ).

Table (4): Outcome measures in the studied patients of acute theophylline intoxication $(n=31)$

\begin{tabular}{|l|l|c|}
\hline \multicolumn{2}{|c|}{ Outcome measures } & n (\%) \\
\hline \multirow{2}{*}{ Mortality } & Died & $0(0 \%)$ \\
\cline { 2 - 3 } & Survived & $31(100 \%)$ \\
\hline \multirow{2}{*}{ Need for hemodialysis } & Yes & $1(3.2 \%)$ \\
\cline { 2 - 3 } & No & $30(96.8 \%)$ \\
\hline \multirow{2}{*}{ Intensive care unit admission } & Yes & $3(9.7 \%)$ \\
\cline { 2 - 3 } & No & $28(90.3 \%)$ \\
\hline \multirow{2}{*}{ Duration of hospital stay (hours) } & Range & $24.0-96.0$ \\
\cline { 2 - 3 } & Mean \pm SD & $45.9 \pm 19.5$ \\
\hline
\end{tabular}

n: number, SD: standard deviation.

Regarding troponin I level at time of admission, there was significant difference between cases with mild theophylline intoxication and cases with severe theophylline intoxication $(p<0.001)$. On the other hand, cases with mild intoxication showed no significant difference compared to cases with moderate intoxication. Additionally, there was no significant difference between cases with moderate intoxication and severe intoxication. Similar results were obtained regarding troponin I level 12 hours post admission. Both troponin I levels at time of admission and 12 hours post admission were significantly higher in cases required ICU compared to cases not admitted to ICU (Table 5). 
Table (5): Troponin I at time of admission and 12 hours post admission levels against acute theophylline toxicity grading and intensive care unit admission in studied patients of acute theophylline toxicity $(\mathrm{n}=31)$

\begin{tabular}{|c|c|c|c|c|c|c|}
\hline & & \multicolumn{2}{|c|}{ Troponin I (1) } & \multicolumn{3}{|c|}{ Tests of significance } \\
\hline & & $\begin{array}{l}\text { Median } \\
(\mathrm{ng} / \mathrm{ml}) \\
\end{array}$ & $\begin{array}{c}\text { IQR } \\
(\mathrm{ng} / \mathrm{ml}) \\
\end{array}$ & $\begin{array}{l}\text { Mean } \\
\text { ranks }\end{array}$ & Test statistic & $p$-value \\
\hline \multirow{3}{*}{$\begin{array}{l}\text { Acute theophylline } \\
\text { toxicity grading }\end{array}$} & Mild & 0.08 & $0.08-0.08$ & 11.5 & \multirow{3}{*}{$Z_{\mathrm{KW}}=19.219$} & $<0.001^{*}$ \\
\hline & Moderate & 0.08 & $0.08-0.09$ & 17.5 & & Mild-moderate $=0.606$ \\
\hline & Severe & 1.20 & $1.20-1.40$ & 27.9 & & $\begin{array}{l}\text { Mild-severe }<0.001 * \\
\text { Moderate-severe }=0.155\end{array}$ \\
\hline \multirow{2}{*}{$\begin{array}{l}\text { Intensive care unit } \\
\text { admission }\end{array}$} & No & 0.08 & $0.08-0.09$ & 14.7 & \multirow{2}{*}{$Z_{M W}=2.593$} & \multirow{2}{*}{$0.010^{*}$} \\
\hline & Yes & 1.20 & $1.20-1.40$ & 28.2 & & \\
\hline & & \multicolumn{2}{|c|}{ Troponin I (2) } & \multicolumn{3}{|c|}{ Tests of significance } \\
\hline & & $\begin{array}{l}\text { Median } \\
(\mathrm{ng} / \mathrm{ml}) \\
\end{array}$ & $\begin{array}{c}\text { IQR } \\
(\mathrm{ng} / \mathrm{ml}) \\
\end{array}$ & $\begin{array}{l}\text { Mean } \\
\text { ranks }\end{array}$ & Test statistic & $p$-value \\
\hline \multirow{3}{*}{$\begin{array}{l}\text { Acute theophylline } \\
\text { toxicity grading }\end{array}$} & Mild & 0.01 & $0.01-0.02$ & 11.4 & \multirow{3}{*}{$Z_{\mathrm{KW}}=20.511$} & $<0.001^{*}$ \\
\hline & Moderate & 0.06 & $0.02-0.11$ & 18.3 & & Mild-moderate $=0.406$ \\
\hline & Severe & 2.10 & $2.00-2.30$ & 28.0 & & $\begin{array}{l}\text { Mild-severe }<0.001 * \\
\text { Moderate-severe }=0.196\end{array}$ \\
\hline \multirow{2}{*}{$\begin{array}{l}\text { Intensive care unit } \\
\text { admission }\end{array}$} & No & 0.01 & $0.01-0.09$ & 14.6 & \multirow{2}{*}{$\mathrm{Z}_{\mathrm{MW}}=2.807$} & \multirow{2}{*}{$0.005^{*}$} \\
\hline & Yes & 2.30 & $2.00-3.00$ & 29.0 & & \\
\hline
\end{tabular}

Troponin I (1): troponin at time of admission; Troponin I (2): troponin 12 hours post admission; ng: nanogram; ml: milliliter; IQR: interquartile range; ZKW: Kruskal-Wallis test; ZMW: Mann-Whitney test; * significant at $\mathrm{p}<0.05$.

For CK-MB level at time of admission, no significant difference was observed between cases with mild, moderate and severe intoxication. Moreover, it did not show significant difference as regard ICU admission. On the other hand, CK-MB level 12 hours post admission was significantly higher in cases with severe intoxication compared to cases with mild intoxication $(p<0.001)$. However, there was no significant difference between cases with mild and moderate intoxication or cases with moderate and severe intoxication. In addition, CK-MB level 12 hours post admission was significantly higher in patients who were indicated for ICU admission than those who did not require ICU admission (Table 6). 
Table (6): Creatine kinase-MB at time of admission and 12 hours post admission against acute theophylline toxicity grading and intensive care unit admission in studied patients of acute theophylline toxicity $(\mathrm{n}=31)$

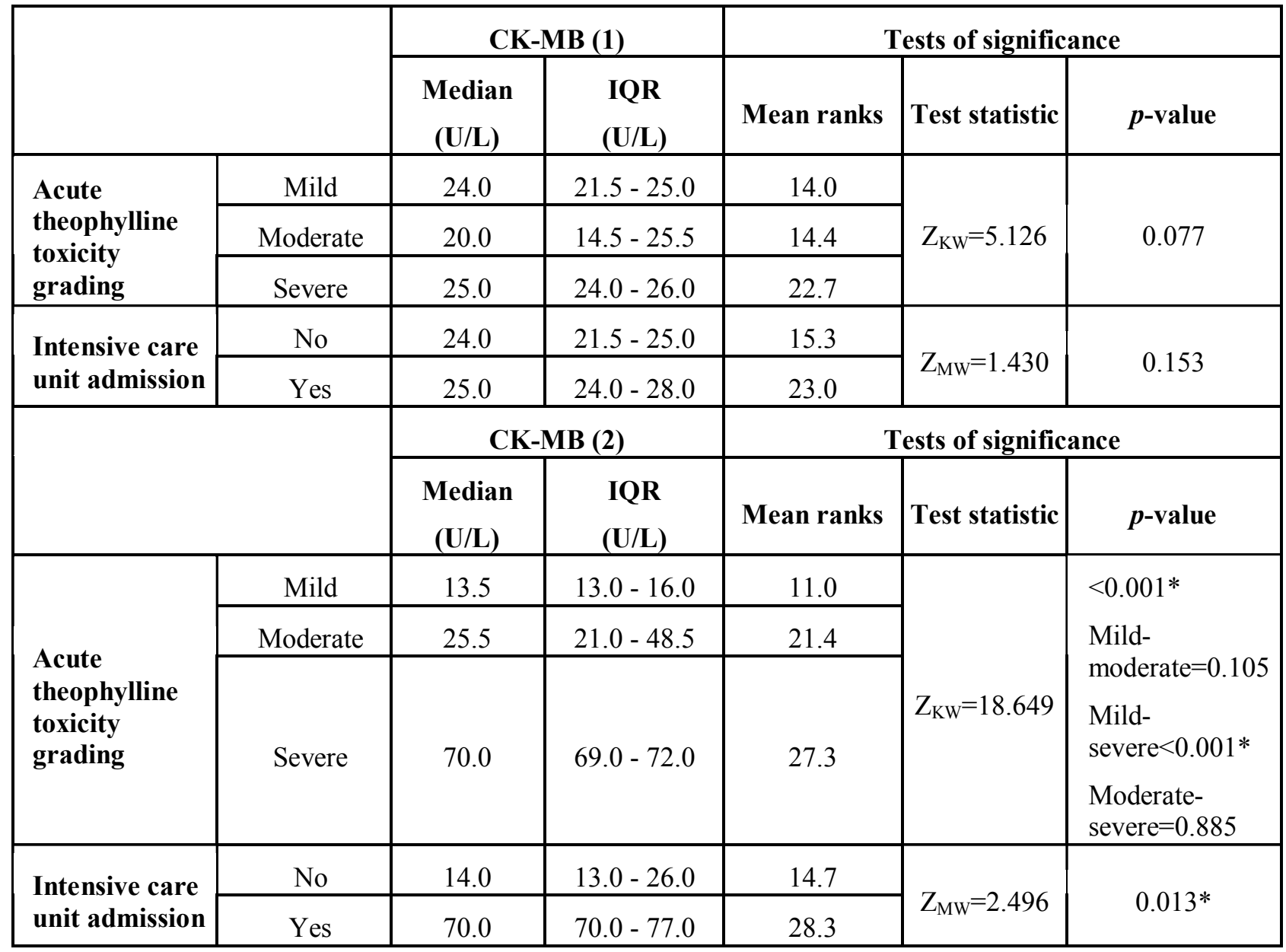

CK-MB (1): creatine kinase-MB at admission; CK-MB (2): creatine kinase-MB 12 hours post admission; U: unit; L: liter; IQR: interquartile range; ZMW: Mann-Whitney test; ZKW: Kruskal-Wallis test; * significant at $\mathrm{p}<0.05$.

According ROC curve analysis, each of troponin I (1), troponin I (2) and CK-MB (2) showed excellent performance in predicting the requirement of ICU admission in patients with acute theophylline intoxication with AUCs $0.935,0.964$ and 0.940 respectively. Whereas, CK-MB (1) had fair performance
(AUC: 0.75). Optimum cut off values of troponin I (1), troponin I (2), CK-MB (1) and CK-MB (2) were $>0.1 \mathrm{ng} / \mathrm{ml},>0.3 \mathrm{ng} / \mathrm{ml},>23$ $\mathrm{U} / \mathrm{L}$ and $>69 \mathrm{U} / \mathrm{L}$ respectively. Pairwise comparisons revealed no significant difference among the four parameters (Table 7). 
Table (7): Areas under the curve, optimum cut-off values, sensitivities and specificities of troponin $\mathrm{I}$ and $\mathrm{CK}-\mathrm{MB}$ in predicting the requirement of intensive care unit admission in the studied patients of acute theophylline intoxication $(n=31)$

\begin{tabular}{|c|c|c|c|c|}
\hline & Troponin I (1) & Troponin I (2) & CK-MB (1) & CK-MB (2) \\
\hline $\begin{array}{l}\text { AUC } \\
(95 \% \text { CI }) \\
\end{array}$ & $\begin{array}{c}0.935 \\
(0.784-0.992) \\
\end{array}$ & $\begin{array}{c}0.964 \\
(0.828-0.999) \\
\end{array}$ & $\begin{array}{c}0.750 \\
(0.563-0.887) \\
\end{array}$ & $\begin{array}{c}0.940 \\
(0.793-0.994) \\
\end{array}$ \\
\hline$P$-value & $<0.001^{*}$ & $<0.001 *$ & $<0.001 *$ & $<0.001 *$ \\
\hline Cut off value & $>0.1 \mathrm{ng} / \mathrm{ml}$ & $>0.3 \mathrm{ng} / \mathrm{ml}$ & $>23 \mathrm{U} / \mathrm{L}$ & $>69 \mathrm{U} / \mathrm{L}$ \\
\hline Sensitivity \% & 100.0 & 100.0 & 100.0 & 100.0 \\
\hline Specificity \% & 89.3 & 89.3 & 39.3 & 89.3 \\
\hline \multicolumn{5}{|c|}{ Pairwise comparisons } \\
\hline Troponin I (1) & & 0.375 & 0.241 & 0.932 \\
\hline Troponin I (2) & 0.375 & & 0.216 & 0.726 \\
\hline CK-MB (1) & 0.241 & 0.216 & & 0.137 \\
\hline CK-MB (2) & 0.932 & 0.726 & 0.137 & \\
\hline
\end{tabular}

Troponin I (1): troponin at time of admission; Troponin I (2): troponin 12 hours post admission; CK-MB (1): creatine kinase-MB at admission; CK-MB (2): creatine kinase-MB 12 hours post admission; AUC: area under the curve; CI: confidence interval; ng: nanogram; ml: milliliter; $\mathrm{U}$ : unit; L: liter; ${ }^{*}$ significant at $\mathrm{p}$ $<0.05$.

\section{Discussion}

Theophylline is a bronchodilator medication that is used for asthmatic patients, in addition to its use to treat bradycardia and apnea in newborns. However, it has a narrow therapeutic window and associated with potentially serious manifestations in acute overdose even with levels slightly above the therapeutic window (Schoen et al., 2014 and Greene et al., 2018).

Predicting the severity and outcomes of patients with acute poisoning is highly important to guide treatment. On the other hand, there is shortage of researches concerning the prediction of the outcomes of cases with acute theophylline intoxication (Abuelfadl et al., 2017). Cardiovascular manifestations are known to be major consequences of acute theophylline intoxication (Starakis et al., 2003 and Hocaoğlu et al., 2014). However, little is known about the role of cardiac biomarkers in such patients. Thereafter, the current study was designed to investigate troponin I and CK-MB as predictor markers of the severity and outcomes in patients with acute theophylline toxicity.

The current study was conducted on 31 patients with acute theophylline intoxication admitted to Tanta Poison Control Center. Sociodemographic data of the current study revealed that, the mean value of age was 22.9 years and students represented the major part of the studied patients. Different researches revealed that, the rate of suicide increases among young adults due to inability to face life challenges, depression and anger (Shannon, 1999 and Hooven et al., 2012). The predominance of females in the current study $(74.2 \%)$ was in accordance with Hocaoğlu et al. (2014) where 
females represented $72.6 \%$ of their studied population. In the current study, $87.1 \%$ were moderately educated while $12.9 \%$ were highly educated. This was partially in line with Abuelfadl et al. (2017) who found that, $39.29 \%$ of the studied cases were moderately educated while $32.14 \%$ were highly educated and the remaining were illiterate or just read and write.

Patients from urban areas represented $80.6 \%$ of the studied cases. Pattern of acute poisoning may be influenced by the area of residence; intentional poisoning with pharmaceutical agent in urban area may be more common than rural areas where pesticides and other related compounds are widely used for suicide. Regarding marital status, $67.7 \%$ of the studied patients were single; according to Azizpour et al. (2016), single people may suffer unstable life and loneliness feelings with increased risk for suicidal attempts. The majority of the studied patients were non-smoker; this could be explained by a finding that, the majority of cases in the current study were females. According to Loffredo et al. (2015), Egyptian females are rarely reported to smoke cigarettes.

Concerning mode of poisoning, patients with alleged suicides represented $87.1 \%$ of cases involved in the current study; this could be explained by wide availability of theophylline preparations. It was observed that, sustained-release preparations were incorporated in $83.9 \%$ of the studied case. Elhawary et al. (2015) reported that, $63.33 \%$ of acute theophylline intoxicated patients were due to sustained-release preparations. This is supported by the fact that, theophylline is commonly available in sustained-release formulations because of its relatively short half-life ( 8 hours in adults) (Rajalakshmi et al., 2011). Pre-hospitalization period in the current study ranged between
0.5 and 13 hours; appearance of symptoms, availability of transportation and distance of hospitals could influence pre-hospitalization period (Peranantham et al., 2014).

Regarding clinical manifestations, nausea, vomiting, tachycardia and hypotension were the most common manifestations. Nausea and vomiting were observed in $100 \%$ and $96.8 \%$ of the studied cases respectively; however Hafez (2018) reported vomiting in $78 \%$ of cases. Vomiting is a common symptom of acute theophylline toxicity due to inhibition of phosphodiesterase enzyme $\left(\mathrm{PDE}_{4}\right)$ in the chemoreceptor trigger zone with severe repeated vomiting that may resist antiemetic medications (Barnes, 2010). Tachycardia was observed in $93.5 \%$ in the current study. Tachycardia is considered the most common cardiovascular manifestation which is often associated with hypotension. Hypotension occurs as a result of vasodilation, volume loss and reduced cardiac output (Greene et al., 2018).

In this study, both troponin I and CK-MB were sampled at time of admission and after 12 hours post admission. Hachey et al. (2017) stated that, combined measurement of cardiac troponins and $\mathrm{CK}-\mathrm{MB}$ is the most preferred investigation protocol to detect myocardial damage with recommended sampling at presentation and repeated at interval of more than 10 hours.

In the current study, troponin I showed significant difference against theophylline toxicity grading at time of admission and 12 hours post admission. This finding could explain that, troponin I at time of admission and 12 hours post admission were significantly higher in patients who required ICU admission compared to patients who were not indicated for ICU admission. According to Brandenburg et al. (2017), intoxicated patients with severe sequelae are indicated for ICU admission.

Methylxanthines including theophylline cause cardiac side effects in the form of different 
types of arrhythmias, focal necrosis and subendocardial myolysis. In a study conducted by Shannon (1999), he reported that cardiac dysrhythmia of theophylline intoxication was associated with new onset of myocardiac ischaemia. Moreover, autopsy findings in asthmatic patients with methylxanthines therapy revealed multiple areas of myocardial necrosis (Schoen, 1987).

Interestingly, troponin I is not a marker of myocardial infarction only. Nevertheless, it can indicate all forms of cardiac muscle damage. A finding supported by researchers who documented elevated troponin I in the absence of acute ischemic heart disease; a condition that can occur with different pathological condition as well as with cardiotoxic drug overdose such as; theophylline (Huysa et al., 2016).

Unlike troponin I, CK-MB did not show significant difference with acute theophylline toxicity grading at time of admission, while it showed statistical significant difference with acute theophylline toxicity grading 12 hours post admission. Subsequently, CK-MB 12 hour after admission was significantly higher in patients who were admitted to the ICU. In 2000, The American College of Cardiology Committee together with The European Society of Cardiology declared that, troponin $\mathrm{I}$ is only expressed in cardiac muscle and it is highly sensitive to detect even small amounts of myocardial necrosis, myocardial infarction and myocytes damage than CK-MB. As a result, troponin $\mathrm{I}$ is more specific for myocardial damage and elevated when CKMB is still not elevated (Korff et al., 2007). Hence, troponin is recommended to be sampled early due to its higher diagnostic accuracy (Hachey et al., 2017).

According to Collinson et al. (1992), diagnostic sensitivity of CK-MB is $100 \%$ eight hours post admission. Starakis et al. (2003) reported elevation of serum CK-MB level on the second day of hospitalization.
However, Le et al. (2015) removed CK-MB from hospital ordering models without affecting patient care harmfully and saving unnecessary cost.

In the current study, troponin I (1), troponin I (2), CK-MB (1) and CK-MB (2) at cut off values $>0.1 \mathrm{ng} / \mathrm{ml},>0.3 \mathrm{ng} / \mathrm{ml},>23 \mathrm{U} / \mathrm{L}$ and $>69 \mathrm{U} / \mathrm{L}$ respectively were significantly valid $(p<0.05)$ to predict the requirement for ICU admission in acute theophylline intoxicated patients. Acute poisoning could influence the response of patients, so cut off values of different biomarkers should be unique for each poison. Setting up cut off values related to acute toxicological conditions could guide proper management and attains important clinical implications for toxicologists.

\section{Conclusion:}

In the light of data obtained from the current study, troponin I could predict the severity and the requirement of ICU admission in patients with acute theophylline toxicity either with early or delayed presentation. On the other hand, CK-MB could be considered for patients with delayed presentation. Depending on time of admission, proper choosing of the biomarker to be investigated will allow for better evaluation of patients with saving extra cost.

\section{Limitation of the study:}

In the current study, the role of troponin I and CK-MB in predicting the mortality and the need for hemodialysis in acute theophylline toxicity could not be investigated as there was no mortality and only one case required hemodialysis. Additionally, small sample size of the current study is considered another limitation. Further studies on larger samples and in different poison control centers are recommended. 
References:

Abuelfadl, A.A.; Shahin, M.M. and Alghazaly, G.M. (2017): "ECG changes as predictor of mortality and major outcome events in theophylline acutely intoxicated patients". Mansoura Journal of Forensic Medicine and Clinical Toxicology, 25(1):15-26.

Al Qadheeb, N.S. (2012): Theophylline. In: Textbook of Clinical Pediatrics. Hafri, H. A.; Nazer, H.M.; Stapleton, F.B.; et al. $2^{\text {nd }}$ edition. Springer: Berlin, Heidelberg, P.P. 2643-2647.

Altaie, N.; Malik, S. and Robertson, S. (2011): "Theophylline toxicity - A forgotten entity". British Journal of General Practitioners, 4(1):a404.

Azizpour, Y.; Asadollahi, K.; Sayehmiri, K.; et al. (2016): "Epidemiological survey of intentional poisoning suicide during 1993-2013 in Ilam Province, Iran". BMC Public Health, 16(1):902.

Barnes, P.J. (2010): "Theophylline". Pharmaceuticals (Basel), 3(3):725-747.

Brandenburg, R.; Brinkman, S.; de Keizer, N.F.; et al. (2017): "The need for ICU admission in intoxicated patients: a prediction model". Clinical Toxicology, 25(1):4-11.

Collinson, P.O.; Rosalki, S.B.; Kuwana, T.; et al. (1992): "Early diagnosis of acute myocardial infarction by CK-MB mass measurements". Annals of Clinical Biochemistry, 29:43-47.

Elhawary, A.E.; Elgazzar, F.M. and ElEbiary A.A. (2015): "Predictors of acute theophylline toxicity outcomes". Mansoura Journal of Forensic Medicine and Clinical Toxicology, 23(1):29-49.
Fisher, J. and Graudins, A. (2015): "Intermittent haemodialysis and sustained low-efficiency dialysis (SLED) for acute theophylline toxicity". Journal of Medical Toxicology, 11(3):359-363.

Flomenbaum, N.; Goldfrank, L.; Hoffman, R.; et al. (2006): Initial evaluation of the patient: Vital signs and toxic syndromes. In: Goldfrank's Toxicological Emergencies. Flomenbaum, N.; Goldfrank, L.; Hoffman, R.; et al. (Eds.), 8th Edition. McGrw-Hill: London, P.P. 37- 42.

Greene, S.C.; Halmer, T.; Carey, J.M.; et al. (2018): "Theophylline toxicity: An old poisoning for a new generation of physicians". Turkish Journal of Emergency Medicine, 18(1):37-39.

Hachey, B.J.; Kontos, M.C.; Newby, L.K.; et al. (2017): "Trends in use of biomarker protocols for the evaluation of possible myocardial infarction". Journal of the American Heart Association, 6(9):e005852.

Hafez, R.N. (2018): "Serum theophylline level as predictor for complications in adults with acute theophylline overdose". Ain Shams Journal of Forensic Medicine and Clinical Toxicology, 30:18-26.

Henry, J. and Minton, N. (2011): "Treatment of theophylline overdose". American Journal of Emergency Medicine, 14:606612.

Hocaoğlu, N.; Yıldıztepe, E.; Bayram, B.; et al. (2014): "Demographic and clinical characteristics of theophylline exposures between 1993 and 2011". Balkan Medical Journal, 31(4):322-327.

Hooven, C.; Snedker, K.A. and Thompson, E.A. (2012): "Suicide risk at young adulthood: Continuities and discontinuities from adolescence" Youth \& Society, 44(4):524-547. 
Hori, Y.; Fujisawa, M. and Shimada, K. (2006): "Method for screening and quantitative determination of serum levels of salicylic acid, acetaminophen, theophylline, phenobarbital, bromvalerylurea, pentobarbital, and amobarbital using liquid chromatography/electrospray mass spectrometry". Biological \& Pharmaceutical Bulletin Journal, 29(1):7-13.

Huysa, K.; Budak, Y.U.; Aydin, U.; et al. (2016): "COHb level and highsensitivity cardiac troponin $\mathrm{T}$ in 2012 in Bursa, Turkey: A retrospective singlecenter study". Iranian Red Crescent Medical Journal, 18(5):e27061.

Kokholm, G. (1990): "Simultaneous measurements of blood $\mathrm{pH}, \mathrm{PCO} 2, \mathrm{PO} 2$ and concentrations of hemoglobin and its derivatives-A multicentre study". Scandavian Journal of Clinical and Laboratory Investigation Supplements, 203:75-86.

Korff, S.; Katus, H.A. and Giannitsis, E. (2007): "Differential diagnosis of elevated troponins". BMJ, 92(7):987993.

Le, R.D.; Kosowsky, J.M.; Landman, A.B.; et al. (2015): "Clinical and financial impact of removing creatine kinase-MB from the routine testing menu in the emergency setting". American Journal of Emergency Medicine, 33(1):72-75.

Lim, S.; Tan, S.; Tai, D.; et al. (2005): "Successful treatment of theophylline toxicity with continuous venovenous hemofiltration". Critical Care and Shock Journal, 8:96-97.

Loffredo, C.A.; Radwan, G.N.; Eltahlawy, E.M.; et al. (2015): "Estimates of the prevalence of tobacco smoking in Egypt". Open Journal of Epidemiology, 5:129-135.
Middleton, S (2008): Assessment and investigations of patients' problems. In: Physiotherapy for Respiratory and Cardiac Problems. Pryor, J.A. and Prasad, S.A. (Eds.), $4^{\text {th }}$ Edition. Churchill Livingston, Elsevier, P.P. 8-9.

Murray, L. (2015): Theophylline. In: Textbook of Adult Emergency Medicine. Cameron, P.; Jelinek, G.; Kelly, A.; et al. (Eds). $4^{\text {th }}$ edition. Churchill Livingstone Elsevier, P.P. 993-998.

Nasir, M.; Abd Halim, N.N.; Ahmad, R. and Baharuddin, K.A. (2009): "Theophylline toxicity: A case report of the survival of an undiagnosed patient who presented to the emergency department". Malaysian Journal of Medical Science, 16(2):33-37.

Navid, A.; Ng, M.D.; Wong, S.E. and Lightstone, F.C. (2016): "Application of a physiologically based pharmacokinetic model to study theophylline metabolism and its interactions with ciprofloxacin and caffeine". CPT Pharmacometrics Systems Pharmacology, 5(2):74-81.

Paul, S.; Saba, M. and Berger, K. (2010): "Theophylline in asthma". Journal of Asthma \& Allergy Educator, 1(5):180-182.

Peranantham, S.; Shaha, K.K.; Sahai, A.; et al. (2014): "Hospital based epidemiological study of deaths due to organophosphorous compound poisoning". Indo American Journal of Pharmaceutical Research, 4(9):3773-3779.

Rajalakshmi, G.; Balachandar, R. and Damodharan, N. (2011): "Formulation and evaluation of theophylline sustained release matrix tablet". Scholars Research Library, 3(6):1-7.

Schoen, F.J. (1987): "Cardiac pathology in asthma". Journal of Allergy and Clinical Immunology, 80(3):419-423. 
Schoen, K.; Yu, T.; Stockmann, C.; et al. (2014): "Use of methylxanthine therapies for the treatment and prevention of apnea of prematurity". Paediatric Drugs, 16(2):169-177.

Shamsuzzaman, M.; Kavita, G. and Arunabha, R. (2016): "Methylxanthine induced cardiotoxicity and its mechanisms: An experimental study". Manipal Journal of Medical Sciences, 1(2):10-19.

Shannon, M. (1999): "Life threatening events after theophylline overdose". Archives of Internal Medicine Journal, 159:989994.

Shannon, M. (2007): Theophylline and caffeine. In Haddad and Winchester Clinical Management of Poisoning and Drug Overdose. Shannon, M.; Borron, S. and Burns, M. (Eds.). $4^{\text {th }}$ edition. Elsevier Inc Company: Philadelphia, P.P. 1035-1049.

Shannon, M. and Perry, E. (2005): Theophylline and other Methyl Xanthine. In: Critical Care Toxicology: Diagnosis and Management of the Critically Poisoned Patients. Brent, J.
(Eds.). $1^{\text {st }}$ edition. Elsevier Health Sciences, Ch. 40, P.P. 458-464.

Sheehan, M. and Haythorn, P. (1976): "Rapid gas chromatographic determination of underivatized theophylline in whole blood". Journal of Chromatography, 117:392-398.

Starakis, I.; Lekkou, A.; Blikas, A. and Labropoulou-Karatza, C. (2003): "Druginduced cardiotoxicity due to aminophylline treatment: A case report". Current Therapeutic Research, Clinical and Experimental, 64(6):367-374.

Trinder, P. (1969): "Determination of glucose in blood using glucose oxidase with an alternative oxygen acceptor". Annals of Clinical Biochemistry, 6:24-27.

Wilson, C.N. (2008): "Adenosine receptors and asthma in humans". British Journal of Pharmacology, 155:475-486.

Woo, O.F. (1999): Organophosphates and carbamates. In: Poisoning and Drug Overdose. Anderson, I.B. and Clark, R.F. (Eds.), $3^{\text {rd }}$ Edition. Appleton \& Lange, Stanford, P.P. 224-248. 


\section{تروبونين اي مقابل كرياتيز كينازاجبي كمؤشرات تنبؤية لشدة و نتائج التسمم الحاد بالثيوفيللين}

\section{علياء عبد الحكم هليببو مني محمد غنيي}

قسم الطب الثرعي والسموم الإكلينيكية كليه الطب - جامعة طنطا

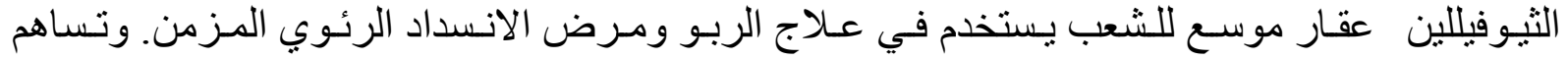

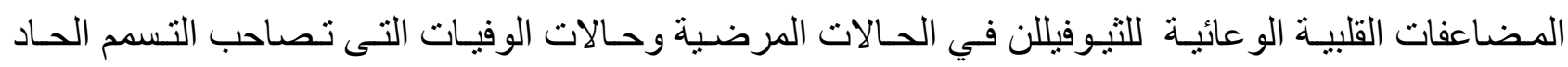
بالثيوفيللين. وتهدف هذه الدر اسة إلي فحص تروبونين ابي وكرياتين كينـاز امبهي كمتنبئات لثدة ونتائج حالات التسمم الحاد بالثيوفيلين. وقد تم إجر اء الدر اسة على واحد وثثلاثين مريضأ يعانون مـن التسمم الحساد بـالثيوفيللين

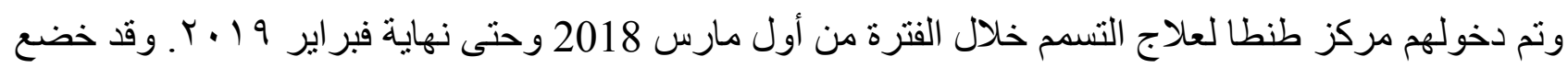

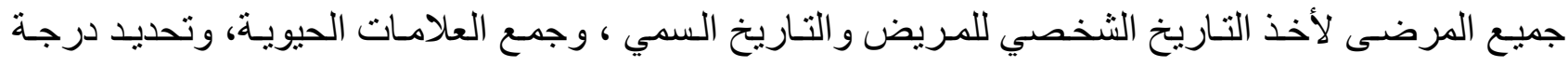
التسمم الحاد للثيوفيلين، وقياس مستوى الثيوفيلين في الدم. وقد تم قياس كل من نروبونين ابي وكرياتين كينـاز ام-

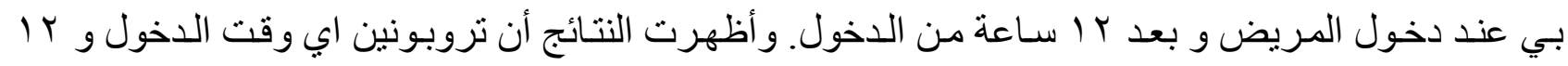

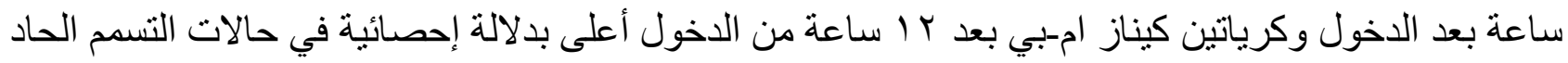

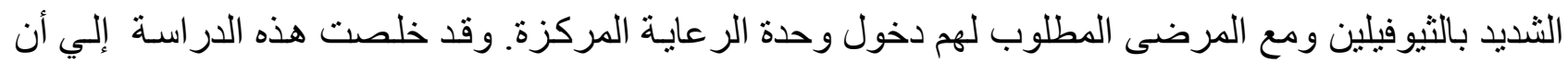

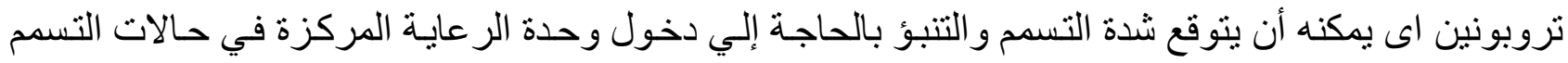

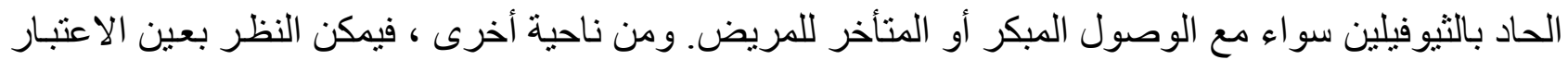
لكرياتين كيناز ام-بي للمرضى في حالة الوصول بهو المتأخر. 